\title{
Origin and Regional Setting of Metropolises in India
}

\author{
Jitendra Kumar \\ Department of Geography, K.L.P. College, Rewari, India \\ Email: jitendrakumar99@gmail.com
}

Received 28 June 2014; revised 22 July 2014; accepted 23 August 2014

Copyright (C) 2014 by author and Scientific Research Publishing Inc.

This work is licensed under the Creative Commons Attribution International License (CC BY). http://creativecommons.org/licenses/by/4.0/

\section{cC) (7) Open Access}

\begin{abstract}
The present study has examined in geographic perspective of origin and regional setting of metropolises that constitute an important component of Indian urban system. These are the spatial expression of urban perspective and have acted as focal points on the cultural landscape of India. They continue to play a major role in India's emergence as a premier industrial and political power in the world. The origin of the 52 cities that have acquired the status of metropolises in 2011 ranges from $600 \mathrm{BC}$ (Varanasi) to 1960 (Durg-Bhilainagar). These are located in the four physical regions, namely, the great plains of India, the peninsular plateau, the coastal plains and the Himalayan Mountains. Their concentration was relatively high in the northern plains along the river banks and coastal areas in the early historical period. The physical configuration determined their initial location and economic factors their later growth. The medieval period of Indian history was significant from the view point of urban centres. Most of the towns which are metropolises had appeared as administrative, defence and trade points during the medieval period. The new developments in the field of industry, commerce, transport and information technology will be the driving forces in the growth of new metropolises in future.
\end{abstract}

\section{Keywords}

Metropolises, Origin, Regional Setting, Census

\section{Introduction}

India is the second most populous country, comprising about 17.5 percent population of the world. The urbanisation has increased faster than expected in India. In 2011, for the first time, the absolute increase in the urban population is higher than the rural population since independence. It has continued to be top-heavy, oriented towards large cities. This is because of higher demographic growth in larger cities, attributable to both natural in- 
crease in the resident population and higher net in-migration. In turn, this is consistent with the fact that larger cities are generally more efficient in generating growth and attracting investments, thus attracting more population (Kundu, 2011). The Census recognizes three categories of urban places: metropolitan areas, cities and towns. Its typology of urban places is entirely based on the population criterion. Thus, the term "metropolitan area" is applied to places with a population of ten lakh and above whereas "city" refers to places with population one lakh and above in India. Lower down the population size urban places are designated as towns (Ramachandran, 2007). In the present study "metropolitan area" and "metropolis" are referred to a city with a population of at least one million. Mega city refers to a city with a minimum population of 10 million. There are 52 metropolises according to census 2011. These are located in 16 states and one union territory. The metropolises alone account for 42.6 percent urban population in 2011. The present study makes use of data pertaining to census of 1901 to 2011 and focuses on the origin and regional setting of metropolises in India.

\section{Origin of Metropolises}

Metropolises are the spatial expression of urban perspective. These cities have acted as focal points on the cultural landscape of India. They continue to play a major role in India's emergence as a premier industrial and political power in the world. With the origin of cities dating back to Indus valley civilization, their contribution to the evolved cultural landscape has been substantial. The origin of the 52 cities that have acquired the status of metropolises ranges from $600 \mathrm{BC}$ (Varanasi) to 1960 (Durg-Bhilainagar). Based on the classification proposed by Ramachandran (2007) the origin of these cities relates to the following period:

* The Early Historical Period (600 BC to AD 500)

* Medieval Period (AD 600 to AD 1800)

* British Period (AD 1800 to AD 1947) and

* The Post-Independence Period (After 1947).

The periodisation gives a fair idea of the spatial pattern of towns at different times in Indian history.

The oldest existing cities in India-Varanasi and Patna in the north and Madurai and Kanchi in the south, which originated around 500 BC are symbolic of India's long urban heritage. 34 cities had originated in the medieval period. During this period three major port cities, namely, Bombay, Kolkata, Chennai and Delhi had emerged. In the British period, introduction of the railways and modern industry led to the creation of new Industrial Township such as Kanpur, Dhanbad, Asansol and Jamshedpur. The post-Independence period saw the influx of refugees in settlements like Faridabad. Durg-Bhilainagar was the outcome of industrialization (Table 1).

In 1901 Kolkata was the only metropolis of India. Their number had increased to 5 in 1951 and became 23 in 1991. 17 new cities acquired the status of metropolis in 2011 census, taking the total to 52 in 2011 in comparison to 35 in 2001. Majority of them are located in South India. Kerala added six cities (Malapuram, Thrissur, Kannur, Kollam, Kozhikode and Thiruvananthapuram), Maharashtra (Vasai-Vivar and Aurangabad), Rajasthan (Jodhpur and Kota) and Chhattisgarh (Raipur and Durg-Bhilainagar) two each whereas Jammu Kashmir (Srinagar), Madhya Pradesh (Gwalior), Tamil Nadu (Tiruchirappalli) and Uttar Pradesh (Ghaziabad) added each one metropolis in 2011. All these towns are connected through railway network. Of recent these have been connected via emerged transport routes of golden quadrilateral, north-south and east-west corridor and national highways. Golden quadrilateral connects 15 metropolises. 9 cities are located on the north-south corridor and 3 cities on east-west corridor. Three metropolises namely, Delhi, Bangalore and Agra are located on the junction of golden quadrilateral and north-south corridor. Kanpur, the only metropolis located in the junction of golden quadrilateral and east-west corridor (Figure 2). Remaining metropolises are located on the national and state highways junction.

\section{Regional Setting of Metropolises}

Regional setting clearly matters in explaining the economic dynamism and growth of cities and regions in terms of location, comparative advantages, agglomeration factors, proximity etc. Historically, 32 cities had initially emerged as settlements along the banks of the rivers (Table 2). However, regional setting alone does not determine which cities will grow or thrive. National policies, corporate strategies, political significance and the comparative advantages that cities offer in global, regional and local markets determine the importance and future growth of cities. In many cities, national economic policies and investments are mostly the result of government decisions and budget allocations. Governments also promote and/or regulate private or public investments for 
Table 1. Periods of origin of metropolises.

\begin{tabular}{ccc}
\hline Periods & No. of metropolises & \multicolumn{1}{c}{ Name of metropolises } \\
\hline $\begin{array}{c}\text { The Early Historical Period } \\
\text { (600 BC to AD 500) }\end{array}$ & 9 & Varanasi , Patna, Allahabad, Madurai, Surat, Nashik, Kollam, Jabalpur, Kochi \\
$\begin{array}{c}\text { Medieval Period } \\
\text { (AD 600-1800) }\end{array}$ & 34 & $\begin{array}{l}\text { Vijayawada, Srinagar, Thrissur, Tiruchirappalli, Visakhapatnam, Vadodara, Meerut, } \\
\text { Ludhiana, Rajkot, Amritsar, Bhopal, Nagpur, Ghaziabad, Agra, Greater Mumbai. } \\
\text { Hyderabad, Aurangabad, Chennai, Indore, Kolkata, Thiruvananthapuram, } \\
\text { Bangalore, Pune, Jaipur, Vasai-Vivar and Malappuram }\end{array}$ \\
$\begin{array}{c}\text { British Period } \\
(1800-1947)\end{array}$ & 7 & Kanpur, Kannur, Ranchi, Coimbatore, Dhanbad, Asansol, Jamshedpur \\
$\begin{array}{c}\text { The Post-Independence Period } \\
\text { (After 1947) }\end{array}$ & 2 & Faridabad, Durg-Bhilainagar \\
\hline
\end{tabular}

Source: Based on classification of towns proposed by (Ramachandran, 2007: pp. 342-347).

Table 2. India: Characteristics of metropolises.

\begin{tabular}{|c|c|c|c|c|c|c|c|c|}
\hline 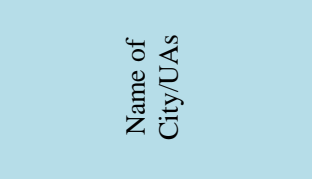 & 岕 & 뭉 귱 & 茎 & 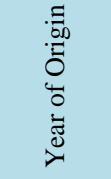 & 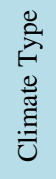 & 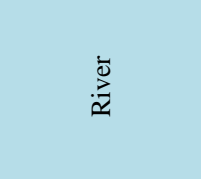 & 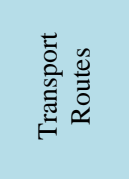 & 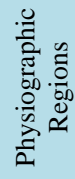 \\
\hline Varanasi UA & Uttar Pradesh & 1.4 & 1991 & $600 \mathrm{BC}$ & $\mathrm{NI}$ & Ganga & GQ & 2 \\
\hline Patna UA & Bihar & 2.0 & 1991 & $400 \mathrm{BC}$ & NI & Ganga & $\mathrm{NH}$ & 2 \\
\hline Allahabad UA & Uttar Pradesh & 1.2 & 2001 & $300 \mathrm{BC}$ & NI & Ganga, Yamuna & GQ & 2 \\
\hline Madurai UA & Tamil Nadu & 1.5 & 1991 & $300 \mathrm{BC}$ & SI & Vaigai & NSC & 4 \\
\hline Surat UA & Gujarat & 4.6 & 1991 & $200 \mathrm{BC}$ & $\mathrm{C}$ & Tapti & GQ & 3 \\
\hline Nashik UA & Maharashtra & 1.6 & 2001 & $200 \mathrm{BC}$ & $\mathrm{P}$ & Godavari & $\mathrm{NH}$ & 4 \\
\hline Kollam UA & Kerala & 1.1 & 2011 & AD 200 & $\mathrm{C}$ & & $\mathrm{NH}$ & 3 \\
\hline Jabalpur UA & Madhya Pradesh & 1.3 & 2001 & 200 & $\mathrm{NI}$ & Narmada & $\mathrm{NH}$ & 4 \\
\hline Kochi UA & Kerala & 2.1 & 1991 & 200 & $\mathrm{C}$ & & NSC & 3 \\
\hline Vijayawada UA & Andhra Pradesh & 1.5 & 2001 & 629 & SI & Krishna & GQ & 3 \\
\hline Srinagar UA & Jammu \& Kashmir & 1.3 & 2011 & 700 & $\mathrm{H}$ & Jhelum & NSC & 1 \\
\hline Thrissur UA & Kerala & 1.9 & 2011 & 800 & $\mathrm{C}$ & & NSC & 3 \\
\hline Tiruchirappalli UA & Tamil Nadu & 1.0 & 2011 & 850 & SI & Cauvery & $\mathrm{NH}$ & 4 \\
\hline Visakhapatnam (M Corp.) & Andhra Pradesh & 1.7 & 1991 & 900 & $\mathrm{C}$ & & GQ & 3 \\
\hline Vadodara UA & Gujarat & 1.8 & 1991 & 1000 & NI & Vishwamitri & GQ & 3 \\
\hline Meerut UA & Uttar Pradesh & 1.4 & 2001 & 1030 & NI & & $\mathrm{NH}$ & 2 \\
\hline Gwalior UA & Madhya Pradesh & 1.1 & 2011 & 1030 & $\mathrm{NI}$ & Chambal & NSC & 4 \\
\hline Delhi UA & NCT of Delhi & 16.3 & 1951 & 1030 & $\mathrm{NI}$ & Yamuna & NSC, GQ & 2 \\
\hline Kota (M Corp.) & Rajasthan & 1.0 & 2011 & 1264 & NI & Chambal & EWC & 4 \\
\hline Kozhikode UA & Kerala & 2.0 & 2011 & 1325 & C & & $\mathrm{NH}$ & 3 \\
\hline Raipur UA & Chhattisgarh & 1.1 & 2011 & 1360 & SI & & $\mathrm{NH}$ & 4 \\
\hline Lucknow UA & Uttar Pradesh & 2.9 & 1981 & 1400 & $\mathrm{NI}$ & Gomati & EWC & 2 \\
\hline Malappuram UA & Kerala & 1.7 & 2011 & 1400 & $\mathrm{C}$ & & $\mathrm{NH}$ & 3 \\
\hline Ahmadabad UA & Gujarat & 6.4 & 1961 & 1413 & NI & Sabarmati & GQ & 3 \\
\hline Jodhpur UA & Rajasthan & 1.1 & 2011 & 1465 & $\mathrm{D}$ & & $\mathrm{NH}$ & 2 \\
\hline Ludhiana (M Corp.) & Punjab & 1.6 & 1991 & 1481 & $\mathrm{NI}$ & Sutlej & NSC & 2 \\
\hline
\end{tabular}


Continued

\begin{tabular}{|c|c|c|c|c|c|c|c|c|}
\hline Rajkot UA & Gujarat & 1.4 & 2001 & 1500 & NI & Aji & EWC & 3 \\
\hline Amritsar UA & Punjab & 1.2 & 2001 & 1500 & NI & & $\mathrm{NH}$ & 2 \\
\hline Bhopal UA & Madhya Pradesh & 1.9 & 1991 & 1500 & $\mathrm{P}$ & Betwa & NH & 4 \\
\hline Nagpur UA & Maharashtra & 2.5 & 1981 & 1500 & SI & & NSC & 4 \\
\hline Ghaziabad UA & Uttar Pradesh & 2.4 & 2011 & 1500 & NI & Hindan & $\mathrm{NH}$ & 2 \\
\hline Agra UA & Uttar Pradesh & 1.8 & 2001 & 1506 & NI & Yamuna & NSC, GQ & 2 \\
\hline Greater Mumbai UA & Maharashtra & 18.4 & 1911 & 1532 & $\mathrm{C}$ & & GQ & 3 \\
\hline Vasai Virar City (M Corp.) & Maharashtra & 1.2 & 2011 & 1534 & $\mathrm{C}$ & & GQ & 3 \\
\hline Hyderabad UA & Andhra Pradesh & 7.7 & 1951 & 1589 & NI & Musi & NSC & 4 \\
\hline Aurangabad UA & Maharashtra & 1.2 & 2011 & 1636 & $\mathrm{P}$ & & NH & 4 \\
\hline Chennai UA & Tamil Nadu & 8.7 & 1951 & 1639 & $\mathrm{C}$ & Adyar \& Cooum & GQ & 3 \\
\hline Indore UA & Madhya Pradesh & 2.2 & 1991 & 1661 & $\mathrm{P}$ & & NH & 4 \\
\hline Kolkata UA & West Bengal & 14.1 & 1901 & 1690 & $\mathrm{C}$ & Hooghly & GQ & 2 \\
\hline Thiruvananthapuram UA & Kerala & 1.7 & 2011 & 1700 & $\mathrm{C}$ & & $\mathrm{NH}$ & 3 \\
\hline Bangalore UA & Karnataka & 8.5 & 1961 & 1700 & $\mathrm{P}$ & & NSC, GQ & 4 \\
\hline Pune UA & Maharashtra & 5.1 & 1971 & 1721 & $\mathrm{P}$ & Mula, Mutha & GQ & 4 \\
\hline Jaipur (M Corp.) & Rajasthan & 3.0 & 1981 & 1730 & NI & Luni & GQ & 4 \\
\hline Kanpur UA & Uttar Pradesh & 2.9 & 1971 & 1800 & NI & Ganga & EWC, GQ & 2 \\
\hline Kannur UA & Kerala & 1.6 & 2011 & 1800 & $\mathrm{C}$ & & NH & 3 \\
\hline Ranchi UA & Jharkhand & 1.2 & 2011 & 1800 & $\mathrm{P}$ & Subarnarekha & $\mathrm{NH}$ & 4 \\
\hline Coimbatore UA & Tamil Nadu & 2.1 & 1991 & 1800 & SI & Noyyal & NSC & 4 \\
\hline Dhanbad UA & Jharkhand & 1.2 & 2001 & 1860 & NI & Damodar & GQ & 4 \\
\hline Asansol UA & West Bengal & 1.2 & 2001 & 1860 & NI & Damodar & GQ & 4 \\
\hline Jamshedpur UA & Jharkhand & 1.3 & 2001 & 1911 & NI & Subarnarekha & NH & 4 \\
\hline Faridabad (M Corp.) & Haryana & 1.4 & 2001 & 1950 & NI & & NH & 2 \\
\hline Durg-Bhilainagar UA & Chhattisgarh & 1.1 & 2011 & 1960 & SI & & $\mathrm{NH}$ & 4 \\
\hline
\end{tabular}

Source: Computed by author and based on Ramachandran, 2007, Final Population Totals, 2011. Population of Cities referred in millions. Notes: Transport Routes symbols indicate the following: GQ — Golden Quadrilateral, NSC—North South Corridor, EWC—East West Corridor, NH—National Highway. Physiographic regions: 1 - The Himalayan Mountains, 2-The Great Plains of North India, 3-The Coastal Plains and 4-The Peninsular Plateau. Climate Types: C—coastal, NI—northern inland, SI—southern inland, P—Plateau, H-hill station and D-Desert type.

the construction of infrastructure and other investments that contribute to urban development like Durag-Bhilainagar, Asansol and Jamshedpur. Central governments in many states are concentrating more attention and resources on particular city-regions to redirect regional or national development like Jharkhand and Madhya Pradesh. In India, urban growth is initially driven by national governments, and then further propelled by local authorities and other factors, such as the private sector. Among 52 metropolises, 14 cities are enjoying the administrative status of state capital and the remaining are the district headquarters except Vasai-Vivar. Delhi is the capital of India. Fundamentally, geographers have approached the study of city on locational and regional bases. Broadly, India has four regions; The Himalayan Mountains, The Great Plains of North India, The Coastal Plains and The Peninsular Plateau. Keeping in view this perspective, Indian metropolises are discussed below.

\subsection{The Himalayan Mountains}

In this region, Srinagar is the only metropolis located on the north-south corridor in Jammu and Kashmir. It had emerged before $\mathrm{AD} 700$. The city is situated in the heart of the Valley on both banks of River Jhelum. It was a native state capital at the time of British rule in 1901. Srinagar is a major trade and tourist centre since historical times. It became metropolis in 2011. 


\subsection{The Great Plains of North India}

14 metropolises are distributed in The Great Plains of North India. Historically, Varanasi (600 BC), Patna (400 BC) and Allahabad (300 BC) are the three oldest cities of India that originated in the early historical period (Table 2). Kanpur had emerged during the British rule whereas Faridabad (1950) had emerged after the country's Independence. Rest of the 9 cities had originated during the medieval period in the Great Plains of India. In 1901, Kolkata was the imperial capital; Lucknow and Agra were provincial capitals; Delhi, Patna, Varanasi, Meerut and Allahabad were divisional headquarters; and Kanpur, Ludhiana and Amritsar acted as district headquarters. Presently, Delhi is the national capital of India, Kolkata and Lucknow are the capitals of West Bengal and Uttar Pradesh states respectively. Remaining metropolises are the district headquarters. In 2011, Uttar Pradesh had seven metropolises (Lucknow, Kanpur, Ghaziabad, Agra, Varanasi, Meerut, Allahabad) Punjab two (Amritsar, Ludhiana) Delhi, Rajasthan (Jodhpur), Bihar (Patna) and Haryana (Faridabad) one each. Ghaziabad and Jodhpur is the newly emerged metropolis of the Great Plains in 2011 census. These cities are located in the northern inland type of climate.

Kolkata, the capital of West Bengal is located on the east bank of the Hooghly River. It is the oldest metropolis of India having acquired the status in 1901. Presently, it is third largest mega city in India as per 2011 census with 14.1 million residents. Kolkata is home to many industrial units operated by large public and private-sector corporations.

Delhi was the capital of British India and came into the existence in 1911. The city has been experiencing rapid growth since independence. It is the second-largest metropolis in India and eighth largest metropolis in the world by population with 16.3 million inhabitants as per 2011 Census. The growth of Faridabad, Agra, Meerut and Ghaziabad has been a continuous process since independence. These cities are the result of the decision taken after the partition of the country to establish an industrial-cum-housing estate to relieve the pressure of population growth in Delhi and also to decentralize the location of industries.

Varanasi, Patna and Allahabad are the oldest religious cities of India situated on the banks of the River Ganga. People refer to Varanasi as "the city of temples" and "the holy city of India". Patna, the capital of Bihar state is an important business centre of eastern India and is a gateway to the world famous Buddhist and Jain pilgrimage centers. Allahabad is also a holy city which was previously known as Prayaga. Lucknow, the capital of India's most populous state of Uttar Pradesh is located on the north-western shore of Gomati river. It has emerged as one of the most important cities of India in terms of modern technology, level of investment, institutional development and a progressive outlook. Kanpur, the largest city of Uttar Pradesh is nestled on the banks of the river Ganga. In the 19th century, Kanpur was an important British garrison town and known for the Indian Mutiny or first war of Independence.

In Punjab state, Amritsar and Ludhiana have traditionally been a trade link to central Asia, Europe and China for the Indian subcontinent. The city of Amritsar is known for its religious significance and cultural vibrancy. Given its location in the border and due to disturbances in the 80s and the 90s the population growth has been generally slow. Jodhpur was formerly the seat of a princely state of the same name, the capital of the kingdom known as Marwar. It is a popular tourist destination.

\subsection{The Coastal Plains}

Fifteen metropolises are located in the east-west coast of India. Historically, Surat has been the oldest city on the coastal plains originated around 200 BC. Kochi and Kollam had originated in AD 600 in the early historical period (Figure 1). Kannur had emerged in the British period. Remaining 11 cities came into the existence in medieval period, in which two largest cities namely; Greater Mumbai and Chennai had originated during this period (Table 1). In 1901, Greater Mumbai and Chennai were presidency capital, Kochi and Thiruvananthapuram were native state capitals and Ahmadabad, Surat, Kozhikode, Visakhapatnam, Malappuram, Kannur and Kollam were district headquarters. Now, Greater Mumbai and Chennai are the state capital of Maharashtra and Tamil Nadu states respectively. Other metropolises are district headquarters except Vasai-Vivar. In 2011, Kerala holds seven, Gujarat four, Maharashtra, Andhra Pradesh two each and West Bengal, Tamil Nadu one each metropolises in the coastal plains. Six metropolises in Kerala (Malapuram, Thrissur, Kannur, Kollam, Kozhikode, Thiruvananthapuram) and one in Maharashtra (Vasai-Vivar) added in the coastal plains in 2011. These cities are located in the coastal type of climate.

Mumbai consists of seven islands joined together by a series of reclamations under Emperor Ashoka of Magadha 


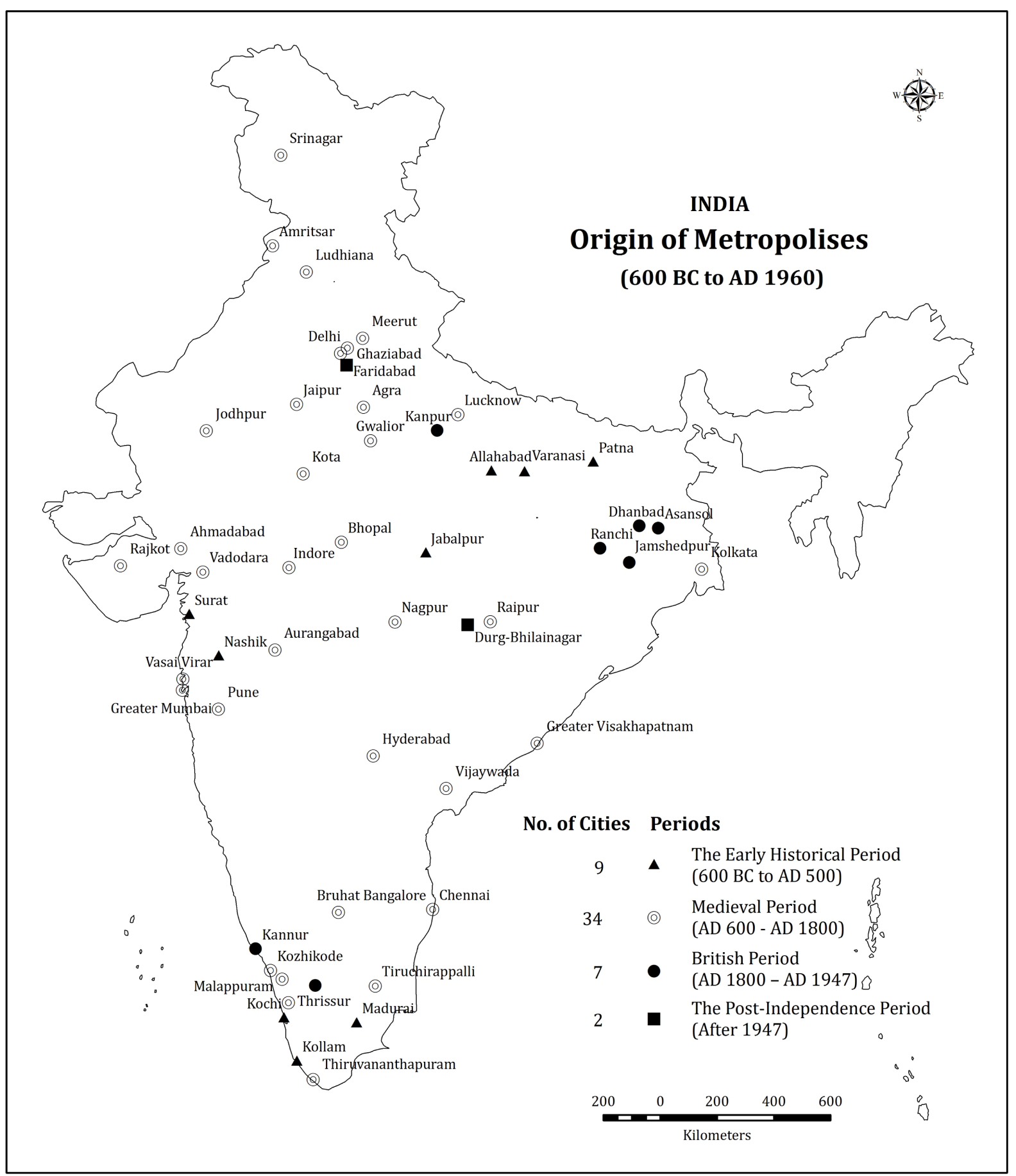

Figure 1. Origin of metropolises in India.

and is an important port city since historic time. It is located on the golden quadrilateral on the western coast. The city is fourth most populous in the world with 18.4 million residents in 2011. Mumbai is one of the world's top commercial centres in terms of global financial flow. Its excellent linkages to major international and domestic destinations are the most preferred inference for manufacturing and new economy industries. Vasai-Virar is a satellite town of Mumbai mega city. It has a significant growth potential due to close proximity of Mumbai. Chennai is the fourth largest metropolis of the country and is experiencing rapid growth in population. It has served as an important administrative, military, and economic centre for many centuries. The history of the city 
began in the colonial times, specifically with the coming of British East India Company. The development of transport corridors and rail connectivity as early as 1900s had attracted industrial developments in the city resulting in increased growth of population. It had become metropolis in 1951. Visakhapatnam is currently ranked as the second largest urban agglomeration in Andhra Pradesh. It is an important port on the east coast.

Gujarat, an industrially developed state has four metropolises-Ahmadabad, Surat, Rajkot and Vadodara. Ahmadabad is the hub of trade and commerce (Figure 2). The city established got as the home of textile industry and earned the nickname of "The Manchester of the East". It is the rising centre of higher education, information technology and scientific industries. Surat is a commercial city located on the river of Tapti. It had become metropolis in 1991. The economic base of city consists of textile manufacturing, trade, diamond cutting and polishing, and chemical industries. Vadodara is one of the focal points of industrial growth in Western India. It runs through the golden corridor, from Ahmadabad to Vapi, and is one of India's foremost industrial centres with dominant groups of chemicals and pharmaceuticals, cotton textiles and machine tools. Rajkot located in the center of Saurashtra region of Gujarat, is situated on western part of India. The city contributes to the economy of the state with heavy and small scale industries.

Kerala has seven metropolises that have emerged in the current decade except Kochi. Kochi, the largest agglomeration in Kerala is the nerve center of all commercial and economic activities in the state. The city is an important administrative and political centre. The importance of trade and the role of the Cochin port is a major reason of development. This area is characterized by comparatively flat terrain and a large expanse of backwaters and canals with small and large islands scattered in the backwaters. All the metropolises which had emerged in 2011 census have rich history. Malappuram was a military head quarter, Kozhikode or Calicut was one of the main commercial or trading cities of Kerala since ancient time. Thiruvananthapuram, the capital of Kerala had originated in AD 1700. The city is characterized by its undulating terrain of low coastal hills with narrow winding lanes and busy commercial alleys. Kannur is of great strategic military importance. It houses military cantonments in the British time. Kollam or Quilon, an old sea port town on the Arabian coast has sustained commercial reputation from the days of the Phoenicians and the Romans. Thrissur is also important for its cultural, spiritual and religious leanings throughout history.

\subsection{The Peninsular Plateau}

The Indian peninsular plateau has 22 metropolises as per 2011 census. Historically, Madurai (300 BC), Nashik (200 BC) and Jabalpur (AD 200) are the oldest cities of the region that originated during the early historical period. Ranchi, Dhanbad, Asansol, Jamshedpur and Coimbatore had emerged during the British period. DuragBhilai is the outcome of government policies after Independence. 16 metropolises had originated during the medieval period. In 1901, Nagpur was the provincial capital; Vijayawada was the native state capital; Pune, Nashik, Coimbatore, Madurai, Tiruchirappalli, Ranchi and Raipur were district headquarters; Hyderabad, Jaipur, Indore, Bhopal, Gwalior, Kota and Aurangabad were native state capitals. Now, Bangalore, Ranchi and Raipur are the state capitals of Karnataka, Jharkhand and Chhattisgarh respectively. Other metropolises are district headquarters. Six metropolises namely, Aurangabad, Kota, Raipur, Durg-Bhilainagar, Gwalior and Tiruchirappalli acquired the status of metropolises in 2011.

Nashik and Madurai are the oldest religious inhabited cities in peninsular region. Nashik is one of the world's holiest Hindu cities. It is known for its pleasant and cool climate, scenic surroundings, high standard of living, greenery and well-developed infrastructure. Madurai city is situated on the bank of river Vaigai which is $500 \mathrm{~km}$ southwest of Chennai in Tamil Nadu. It is a pilgrimage centre and gateway to south Tamil Nadu having the famous Meenakshi temple at its core. Aurangabad city is a tourist hub and surrounded by many historical monuments, like; Ajanta and Ellora Caves which are UNESCO World Heritage sites.

Tiruchirappalli is the transportation center of the state located on the bank of the River Cauvery. During British rule, Tiruchirappalli was known for its tanneries, cigar-manufacturing units and oil presses. Coimbatore grows rapidly after 1930s capitalizing on a textile boom. It has favourable soil, climate and political and economic conditions. The city is situated on the bank of the Noyyal River and surrounded by the Western Ghats on all sides. Coimbatore is well connected by road, rail and air with major towns and cities of India.

Pune is an historical town and once the centre of power of the Maratha Empire. At the time of British India, it served as a cantonment town and the "monsoon capital" of the Bombay Presidency. Nagpur located at the center of the country with the Zero Mile Marker indicating the geographical center of India. The city is major commercial center and famous in the country as "Orange City". 


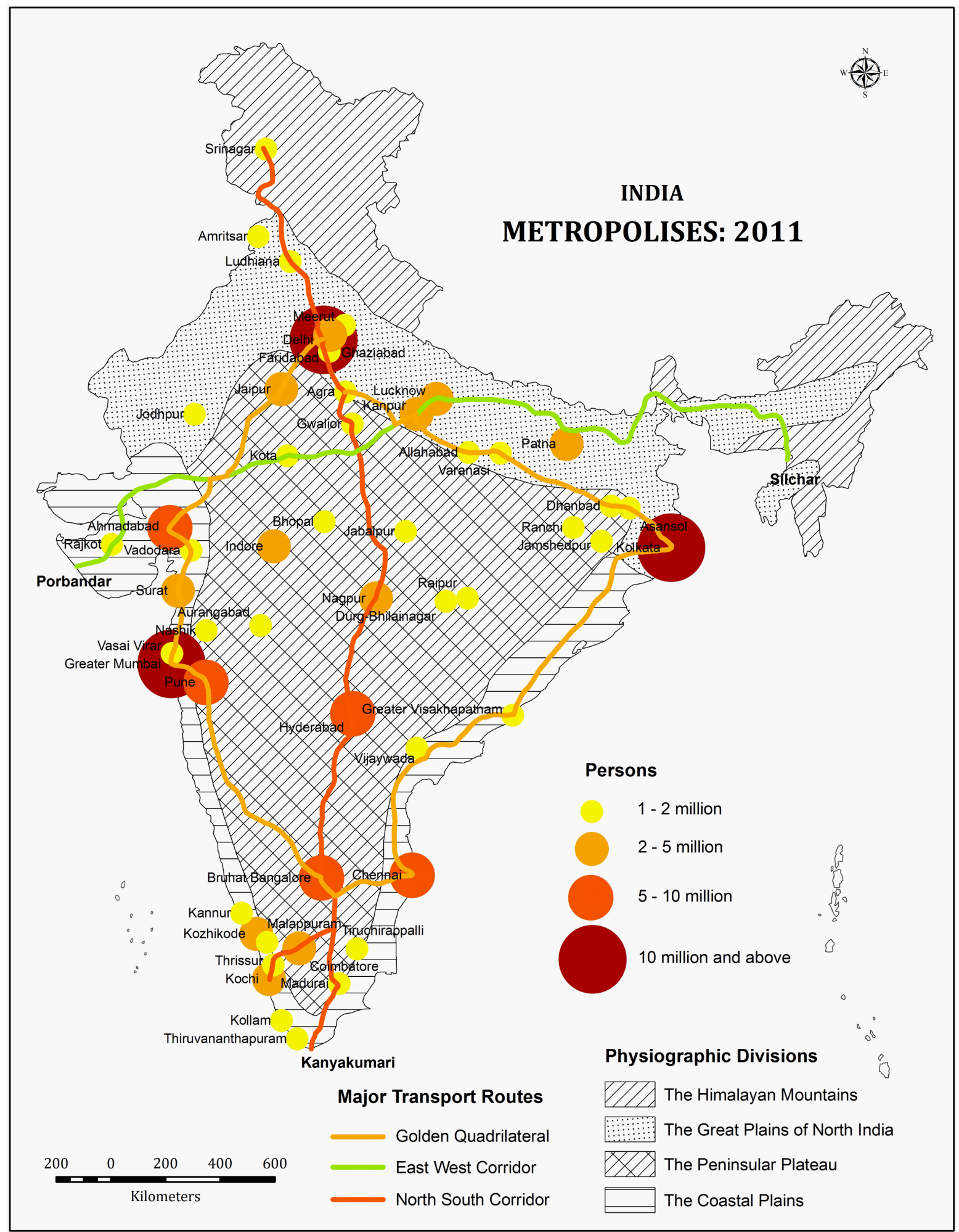

Figure 2. Metropolises in India: 2011.

Jaipur and Bangalore have become hi-tech cities by setting up of I.T. parks. Bangalore is the largest metropolis city of peninsular plateau known as "Silicon Valley". Jaipur is the capital of largest Indian state of Rajasthan, popularly known as the "Pink City”. It was founded on 18 November 1727 by Maharaja Sawai Jai Singh. These 
cities attract huge migrants from the surrounding areas. The growth has been in spite of the industrial slump in the region. These cities offer jobs in commerce, services and the informal sector and show a high economic growth compared to several other Indian cities. Kota is the industrial capital of Rajasthan, located on the eastwest corridor along with eastern bank of Chambal River. It is the smallest metropolis of the 2011 census. The city has good rail and road linkages to other parts of the state.

In central India, Madhya Pradesh accommodates four metropolises-Bhopal, Indore, Jabalpur and Gwalior. Bhopal was founded by Raja Bhoj in the 11th century. It combines the scenic beauty of historical and modern urban planning. Gwalior is a historical city, located from $321 \mathrm{kms}$ to Delhi. It occupies a strategic location in the region of North India. The city has served as the center of several of North India's historic kingdoms. Indore is the most populous metropolis in Madhya Pradesh with population of about 2.2 million as per 2011 census (Table 2). The city has small, mid and large scale manufacturing \& service industries. These industries include automobile, pharmaceutical, software, retail, textile trading and real estate. Jabalpur was became a metropolis in 2001. The city enjoys the status of a regional centre with good connectivity. The primary drivers of the economy of Jabalpur are the service sector and also trade and commerce which contribute to the economy.

Andhra Pradesh has two metropolises namely, Vijayawada and Hyderabad located in the peninsular region. Hyderabad is a major tourist destination in the state having a number of pilgrimage and historical sites. Hyderabad was established in 1589 by Muhammad Quli Qutub Shah. The Nizams (Asif Jahi) ruled the princely state of Hyderabad in a subsidiary alliance with the British Raj for more than two centuries. Presently, Hyderabad Urban Agglomeration is the sixth largest in India with a population of 7.7 million in the year 2011. Vijayawada has considerable historical importance and cultural heritage. It is a major railway junction connecting north and south India, located on the banks of river Krishna. The city region has fertile soil and irrigation which is supported by the river Krishna and its canals. It has a population of 1.5 million as per 2011 census.

After Independence, commerce showed a phenomenal increase with the associated industrial development and establishment of industrial estates, which resulted in the increase of city population. Asansol, Dhanbad, Jamshedpur and Durag-Bhilai which are industrial cities have reported phenomenal growth over the last decade. Bhilai, Durgapur and Rourkela industrial cities were established in completely rural areas for the development process. Ranchi, the capital city of the newly formed Jharkhand, is known for its rich deposits of minerals, waterfalls, rivers, streams, lakes, dams and forests. Raipur, the capital city of Chhattisgarh, has become metropolis in 2011. The city is located near the centre of a large plain, sometimes referred as the "rice bowl of India". Raipur has become an important regional commercial and industrial destination for the coal, power and steel. It has one of the largest markets of steel in India.

\section{Conclusions}

It is observed that 52 metropolises as per 2011 census are located in the four physical regions, namely, the great plains of India, the peninsular plateau, the coastal plains and the Himalayan Mountains. The origin of some of these towns goes as far as about $600 \mathrm{BC}$ (Varanasi). Their concentration was relatively high in the northern plains along the river banks and coastal areas in the early historical period. The physical configuration determined their initial location and economic factors their later growth. The medieval period of Indian history was significant from the view point of urban centres. Most of the towns which are metropolises had appeared as administrative, defence and trade points during the medieval period. Nine largest cities-Mumbai, Delhi, Chennai, Kolkata, Hyderabad, Ahmadabad, Bangalore, Pune and Jaipur had their origin during the medieval period. However some of them grew significantly as a result of the deliberate policy of the British to develop port cities. In the British period, railways and modern industry also led to the creation of new industrial town such as Kanpur, Dhanbad, Asansol and Jamshedpur. The post-independence period saw the influx of refugees in settlements like Faridabad and Durg-Bhilainagar was the outcome of industrialization.

Broadly speaking, most of the cities which are metropolises in 2011 had enjoyed some administrative status in British period. They have continued to dominate the Indian landscape as important administrative, economic, social or cultural centre. All these cities are connected through railway network. Recently these have been connected via emerged transport routes of golden quadrilateral, north-south and east-west corridor and national highways. 17 new cities acquired the status of metropolis in 2011 census are located on these major transport routes. The new developments in the field of industry, commerce, transport and information technology will be the driving forces in the growth of new metropolises in future. 


\section{References}

Kundu, A. (2011). Trends and Processes of Urbanisation in India, Urbanisation and Emerging Population Issues 6. London: Human Settlements Group International, Institute for Environment and Development (IIED) and United Nations Population Fund (UNFPA). http://pubs.iied.org/pdfs/10597IIED.pdf

Ramachandran, R. (2007). Urbanisation and Urban System in India. New Delhi: Oxford Press. 
Scientific Research Publishing (SCIRP) is one of the largest Open Access journal publishers. It is currently publishing more than 200 open access, online, peer-reviewed journals covering a wide range of academic disciplines. SCIRP serves the worldwide academic communities and contributes to the progress and application of science with its publication.

Other selected journals from SCIRP are listed as below. Submit your manuscript to us via either submit@scirp.org or Online Submission Portal.
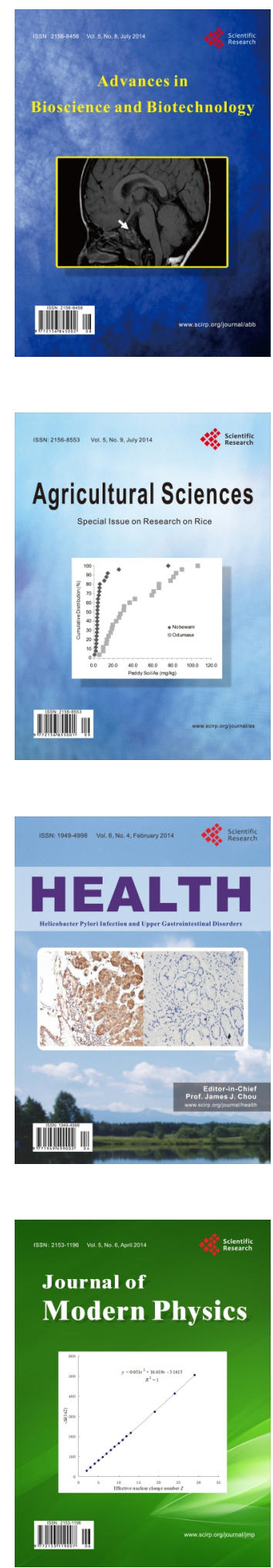
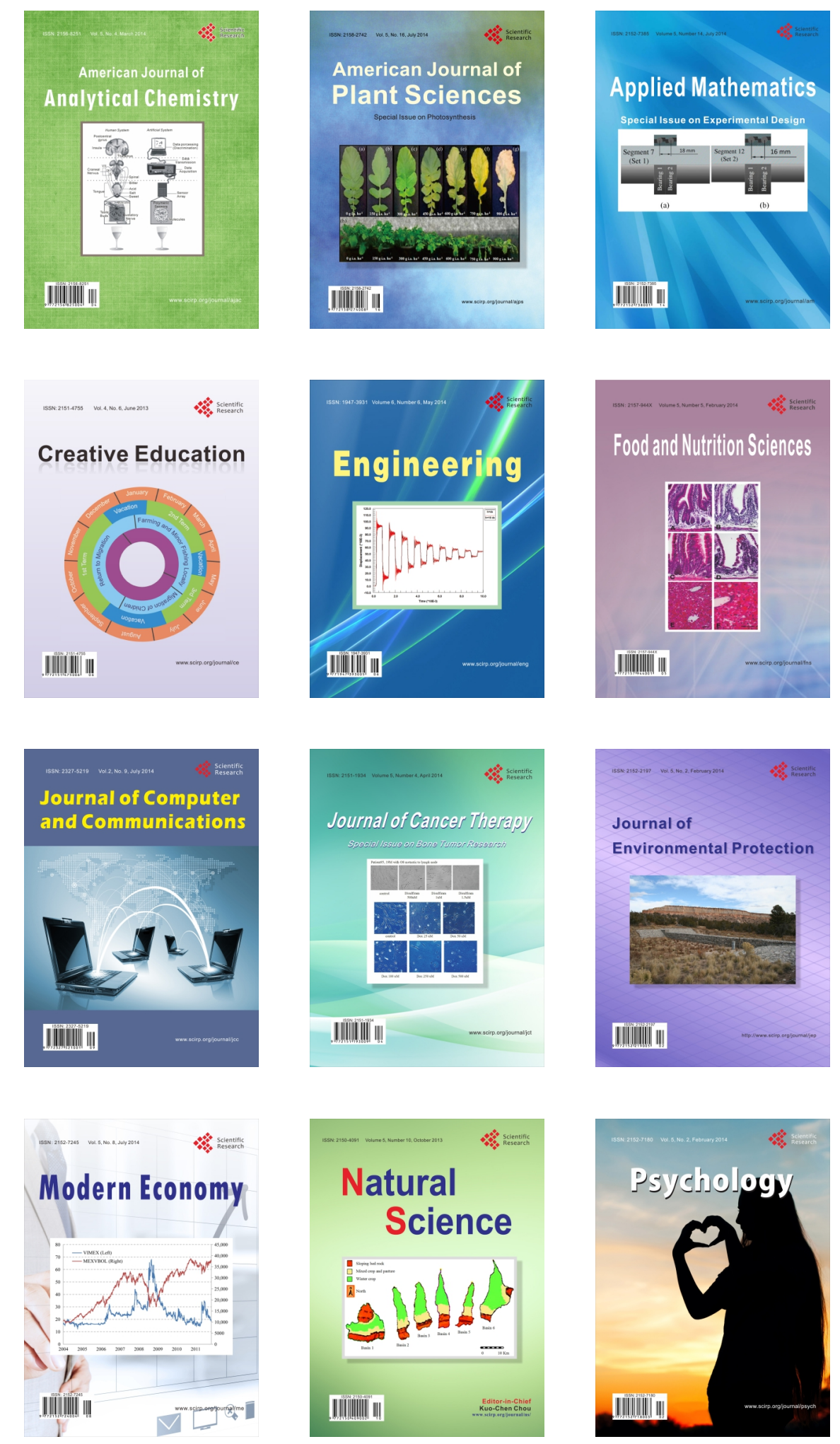